\title{
Horizontal, Vertical And Conglomerate OFDI: Evidence From Thailand
}

Tientip Subhanij, Mahidol University, Thailand

Chitchanok Annonjarn, Bank of Thailand, Thailand

\begin{abstract}
Thailand is a late comer in international expansion but the pace of overseas investment has accelerated in recent years. This paper is the first attempt in exploring the distribution of Thai outward foreign direct investment (OFDI) by types of their investment strategy. Using a unique firm-level FX transaction data, we find that the majority of Thai OFDI is horizontal in nature with vertical and conglomerate investment sharing less than half of the overall total. Horizontal investment is driven mainly by the desire to gain market share and vertical investment by relative factor endowments. Although largely ignored by previous empirical studies, a considerable proportion of Thai OFDI involves conglomerate investment strategy which is driven mainly by financial motives. We also find that Thai companies have simultaneously entered into developed and developing countries, with all types of investment going mostly to developed countries.
\end{abstract}

Keywords: Outward Foreign Direct Investment; Multinational Corporations; Horizontal Investment; Vertical Investment; Conglomerate Investment; Thailand

\section{INTRODUCTION}

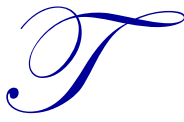

oday, foreign direct investment (FDI) represents one of the most important economic phenomena in the world. The businesses of Multinational Corporations (MNCs) have a wide range of impact on several economic processes. Through investing overseas, MNCs get access to larger markets, lower raw material prices, cheap labour and other benefits that can provide them with more profitability and potential growth.

Traditionally, international investment has been dominated by developed countries. It is usually assumed that FDI flows naturally from the more developed to the less-developed countries, as rich countries tend to have more capital than the less-developed poor nations. In recent years, however, the environment for international investment has changed. The macroeconomic performance of emerging market economies especially in Asia has relatively been much better than most of the developed world. Over the past few decades, therefore, we have seen an increasing role of MNCs from countries other than the most developed ones.

These developing countries' MNCs are from both upper-middle income and middle-income nations. Among these are MNCs from Thailand who are actively extending their global reach. Despite being a late comer in international expansion, Thai companies have rapidly invested abroad. What is striking is that Thai inward and outward flows are converging, with Thailand becoming the exporter of capital for the first time in 2011. The country's ranking among the investor nations worldwide has also improved markedly, from 47th place in 2005 to 37th place in 2013 (UNCTAD, 2014).

The proliferation of Thai outward foreign direct investment (OFDI) is a subject of much debate and raises the question of the patterns, nature and main drivers of Thai international investment. This paper is the first attempt in looking at the patterns and determinants of OFDI using information from the FX transaction database of the Bank of Thailand to distinguish horizontal, vertical as well as conglomerate investment strategies. Our work differs from previous research by uncovering the empirical importance of not only the horizontal and vertical investment but also conglomerate investment which is often ignored in the international economics literature. 
In this paper, we define horizontal investment to occur when firms replicate production by investing in foreign companies in the same industry and on the same stage of the supply-chain, while vertical investment occurs when firms fragment production by investing in foreign companies in different production stage but located within the same value-chain. Conglomerate investment occurs when firms are neither horizontally related through sharing the same industry nor are they vertically connected through the supply-chain.

The paper highlights key features of Thai OFDI that have not been identified in the literature to date. First, we find that substantial parts of Thai OFDI activity do not fit into the established distinction between horizontal and vertical FDI. In particular, conglomerate investment which has been largely ignored by previous empirical studies is in fact far from uncommon with around $20 \%$ of all OFDI transactions being conglomerate strategy. Second, using an augmented gravity model to assess factors driving OFDI, we find that horizontal investment is driven mainly by the desire to gain market share and vertical investment by relative factor endowments. We also find that a considerable proportion of Thai OFDI which involves conglomerate investment is driven mainly by financial motives. Third, in contrast to what is commonly believed that horizontal OFDI usually flows to developed countries to serve the local market and vertical investment to developing countries to source production of intermediate goods, Thai investors have simultaneously entered into developed and developing countries, with all types of investment going mostly to developed countries (Subhanij and Annonjarn, 2014).

The rest of the paper is organized into six further sections. Section 2 summarises previous empirical and theoretical work in this field. Section 3 analyses the recent trend and pattern of Thai OFDI from 2005 to 2013 period. Section 4 discusses the framework in analysing types of OFDI as well as their geographical and sectoral distribution. Section 5 presents the empirical model of OFDI and discussion of results. Section 6 draws the main implications of our findings and concludes.

\section{LITERATURE REVIEW}

In general, firms invest abroad as part of their overall business strategy. This could either be in the form of portfolio investment or direct investment. The former refers to investment in stocks, bonds and other financial products in order to realize higher yields. Direct investment, on the other hand, aims at control over the company established overseas. Although based in foreign countries, foreign MNCs usually have some advantages over local enterprises e.g. better technology, a new or superior product and more efficient process which allow them to compete well with local firms.

In recent years, the global financial landscape which was previously dominated by MNCs from developed countries has changed. There was an emergence of outward direct investment from developing countries. In 2013, developing economies' FDI outflows reached US\$ 454 billion, a record $32 \%$ of the world total, or more than tripled the amount in 2005 (UNCTAD, 2014).

The increasing role of developing countries' MNCs especially those from Asia as significant outward investors has been considered one of the six important changes in the global economic landscape since the 1990s (Dunning, 2009). Despite the ambition to establish a world-class presence, as late comers, these MNCs also need to upgrade capabilities to compete in the global stage. Research has shown that emerging country MNCs sometimes have different investment behaviour from their developed country counterparts (Guillèn and Garcia-Canal, 2009; Kim and Park, 2015).

A strand of literature focuses on the relationship between a country's OFDI and its economic development. Dunning's (1981) investment development path theory suggests that with an increase in per capita income, a country initially attracts an increasing amount of foreign direct investment and subsequently becomes an OFDI player. That is a country moves from less developed stage where the country is a net inward FDI receiver to the more developed stage where it has inward and outward stocks of investment at about the same level (Dunning and Narula, 1996). For Thailand, the rapid expansion of Thai OFDI is a result of both economic development and policy choices. Thailand is a middle-income country with a gross domestic product (GDP) per capita of \$US 5,779 in 2013. With increasing income and growing competitiveness, investing overseas becomes a natural process. This process is accelerated by government policy choices. Since 2007, several financial liberalization measures have been adopted and investing overseas has been encouraged. 
In the literature on multinational corporations (MNCs), two different theories have been advanced in terms of the patterns of FDI, i.e. vertical and horizontal. The horizontal FDI involves replicating production facilities across countries in order to seek access to markets while vertical FDI involves fragmenting stages in the production process in order to access relatively cheaper factor inputs. Horizontal FDI is usually undertaken to avoid the trade costs associated with penetrating new markets, and usually flows between developed countries with similar relative factor endowments (Markusen and Venables, 1998). Vertical FDI, on the other hand, is undertaken by firms looking for cheaper factor of production abroad (Helpman, 1984). These investments typically flow from developed to developing countries which are relatively well-endowed with unskilled labour.

Several past studies suggest that the majority of FDI is horizontal and concentrates between developed countries. Research has also found more support for the horizontal rather than vertical FDI theories. Research on FDI investment strategies include, for example, Helpman (1984), Brainard (1997), Markusen and Venebles (1998), Helpman et al. (2003 and 2004), Alfaro and Charlton 2009) and Herger and McCorriston (2014). The earlier work on these alternative strategies was brought together in a unified framework known as the Knowledge-Capital-model as summarized in Markusen (2002), which suggests that a combination of market size, trade costs, and relative factor endowments determine the pattern of horizontal and vertical FDI strategies.

What proportion of FDI around the world is motivated by horizontal and vertical strategies? Is the theoretical prediction that horizontal FDI is driven by market access considerations whilst vertical FDI rests on exploiting international differences in factor endowments supported by the data? The empirical FDI literature investigating such questions has mainly relied on data about the aggregate FDI figures and hence can provide little empirical evidence on these important hypotheses.

To empirically identify types of FDI in the data has been challenging and unresolved. The empirical results are also often conflicting (Markusen and Maskus, 2002 and Braconier et al., 2005). Alfaro and Charlton (2009) have recently made significant progress on the empirical separation of FDI motives and suggest that an accurate identification of FDI strategies requires detailed information about the industry segments and the vertical relatedness of the different subsidiaries forming MNCs.

For Thailand, there have been very few studies on OFDI, analyzing why and how Thai MNCs invest overseas. These include Pananond (2004), Wee (2007), Cheewatrakoolpong and Boonprakaikawe (forthcoming), and Sermcheep (2013). Previous studies, however, have focused mainly on qualitative exploration of aggregate FDI pattern in general and do not distinguish between types of OFDI which are deemed important in understanding the behavior and pattern of Thai investment overseas. The work that examines determinant of OFDI only uses aggregate OFDI data and focuses on investment in neighbouring countries (Cheewatrakoolpong and Boonprakaikawe, forthcoming). To respond to this research gap, our research examines in detail the patterns of Thai overseas investment as well as their determinants. Specifically, by analyzing the firm-level FX transaction data, we ask "What are the patterns of Thai OFDI and what are the factors that determine different types of outward investment?"

\section{A NEW WAVE OF THAI OFDI: TRENDS AND PATTERNS}

Although Thailand has ventured abroad since 1980s, the amount of outward investment was insignificant due to restrictive outward investment policy and a lack of understanding in internalization (Decharuk et al., 2009). During early 1990s, the financial liberalization policy contributed to the rapid increase of Thai OFDI in manufacturing and service sectors. ${ }^{1}$ Nonetheless, during the financial crisis period (1997-2002) Thai OFDI dramatically declined and Thai affiliates overseas repatriated funds back to their parent companies in order to improve financial positions and survive at home (Wee, 2007).Thai overseas investment has re-emerged after the crisis, particularly since 2005, in line with stronger economic growth and the desire to expand markets. The year 2011 was the first time Thailand transformed itself into a net exporter of direct investment after being a net importer over the past decades. Thai

\footnotetext{
${ }^{1}$ Thailand gave priority to promoting capital inflows through several measures such as eliminating foreign exchange controls, granting tax incentives to encourage FDI and foreign mutual funds as well as establishing the Bangkok International Banking Facility (BIBF) and the Provincial International Banking Facility (PIBF) (Johnston et al.,1997).
} 
OFDI flows reached the peak of US\$12,898 million in 2012, more than 10 times the prior-crisis peak in 1996. Recent experience of Thai investment overseas can be grouped into 2 stages:

(1) A re-emerging stage (2005-2006). The pace of OFDI began to pick up since financial positions and capabilities to venture overseas of Thai companies improved after the crisis. During this time, most of OFDI flows were mainly in the form of equity investment and were undertaken by large enterprises. Thai OFDI during this period was concentrated in terms of sectoral and geographical distribution. They mostly focused on manufacturing and energy sectors while services sector accounted for only a small proportion of the total (Figure 1). In terms of destination, the US and ASEAN were the most attractive countries for Thai MNCs (Figure 2).

Figure 1 Thai OFDI flows classified by sector, 2005-2013

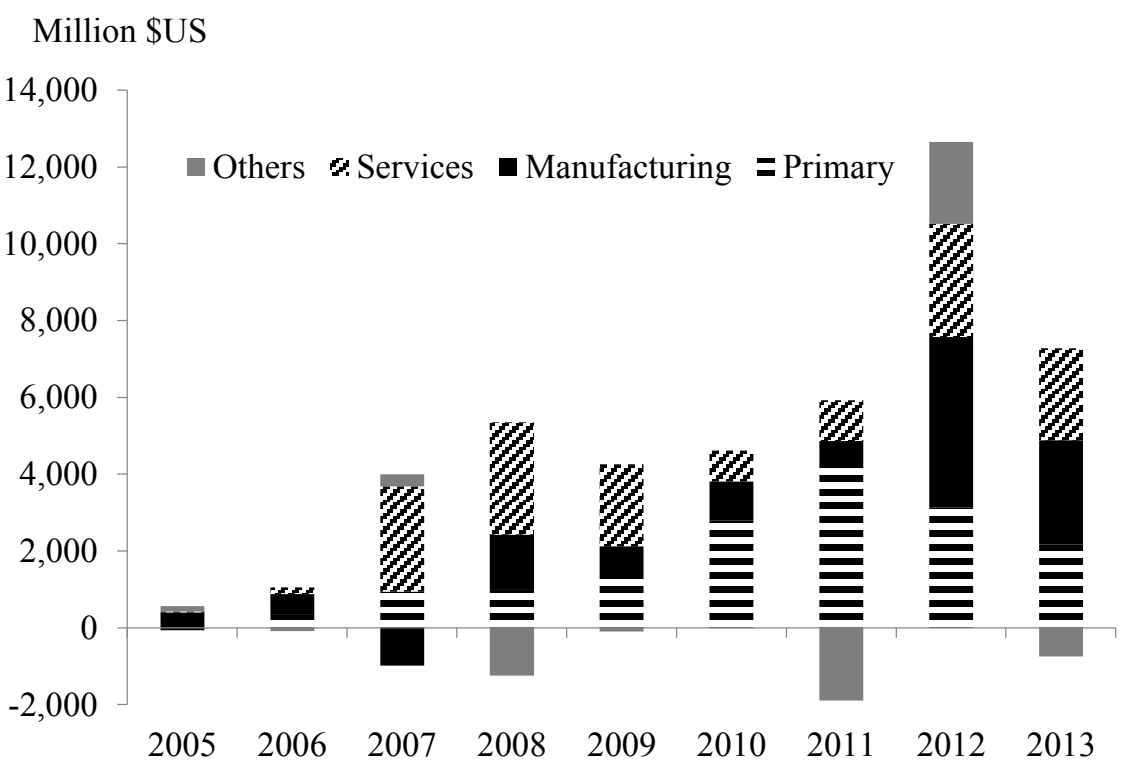

Source: Bank of Thailand

(2) A liberalizing stage (2007- present). The capital outflows liberalization and regional economic integration, particularly ASEAN Economic Community (AEC) are the main catalysts for the surge of Thai OFDI. First-movers from previous years have reinvested and new firms including small and medium sized ones have grown interested in internationalization. Investments in service activities especially trade-supporting services and holding companies have gained importance (Figure 1). In terms of destination, outbound investment has become more diversified. While investing mostly in ASEAN, Thai MNCs have progressively channeled funds to China, Europe, and tax haven countries (Figure 2). ${ }^{2}$

\footnotetext{
${ }^{2}$ According to the Organization for Economic Cooperation and Development (OECD), a tax haven has the following features: (1) no or low taxes, (2) lack of effective exchange of information, (3) lack of transparency, and (4) no requirement of substantial activity (OECD, 1998, cited in Gravelle, 2013). For the case of Thailand, Thai companies invest overseas in 24 tax havens which account for $50 \%$ of total outward direct investment. These tax havens are (1) American Samoa, (2) Bahrain, (3) Bermuda, (4) Cayman Islands, (5) Cyprus, (6) Guernsey, (7) Hong Kong, (8) Ireland, (9) Isle of Man, (10) Jersey, (11) Jordan, (12) Lebanon, (13) Luxembourg, (14) Macau, (15) Maldives, (16) Marshall Islands, (17) Mauritius, (18) Netherlands Antilles, (19) Panama, (20) Singapore, (21) Switzerland, (22) Vanuatu, (23) British Virgin Islands, and (25) U.S. Virgin Islands.
} 
Figure 2 Thai OFDI flows classified by destination

Million US\$

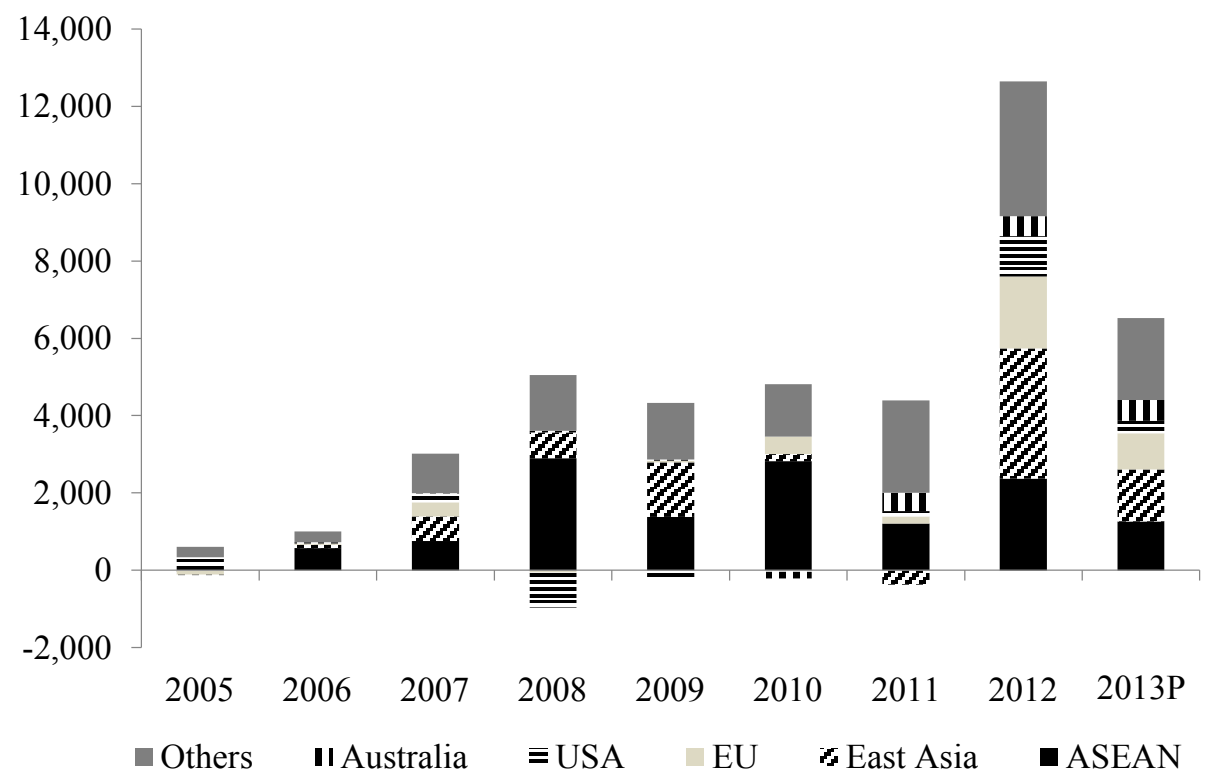

Source: Bank of Thailand

Figure 3 The degree of concentration of Thai OFDI (Herfindahl-Hirschman Index) Index

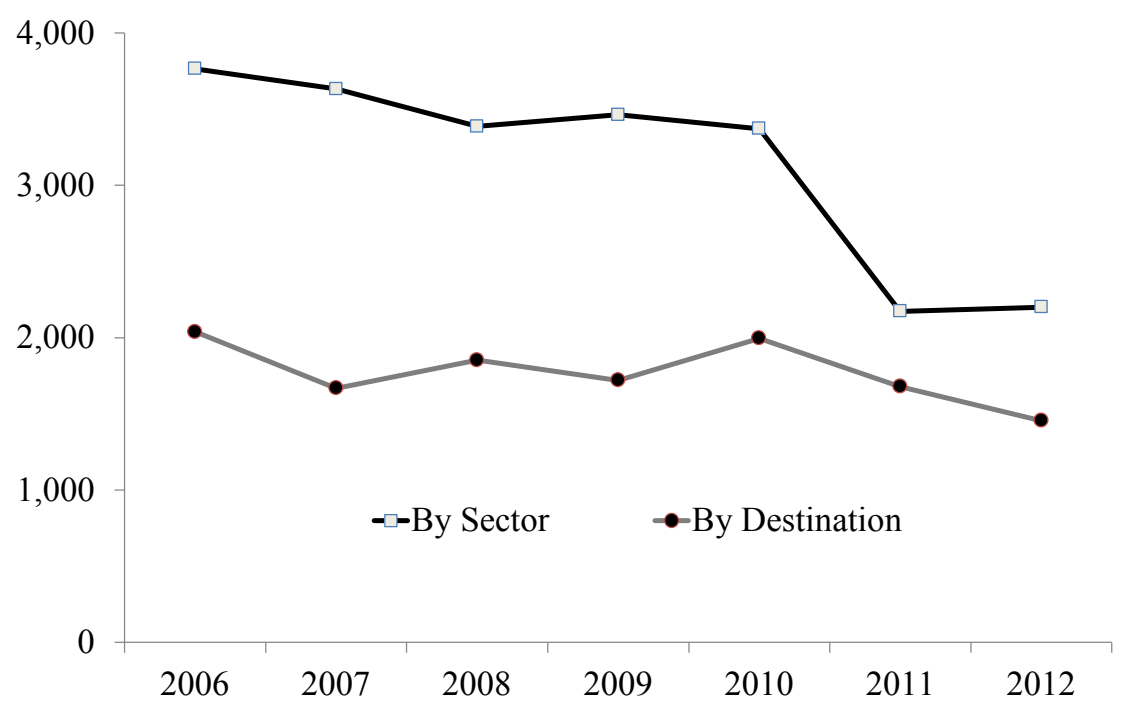

Source: Author's calculation 
Even though Thai OFDI flows have been rising in more diverse businesses and host countries, our calculation of Herfindahl-Hirschman Index (HHI) shows that their stock remains concentrated (Figure 3). ${ }^{3}$ In terms of sector, the concentration has been in services particularly financial and insurance activities and only started to decline since 2011. Thai OFDI is also concentrated in terms of host countries although the degree is less than sectoral concentration. Thai MNCs have invested heavily in ASEAN and countries that provide competitive taxation policy.

\section{DISTINGUISHING HORIZONTAL, VERTICAL, AND CONGLOMERATE THAI OFDI}

\subsection{Concept and Methodology}

Theory usually suggests three main motives for FDI: Market-seeking FDI, efficiency seeking FDI and resourceseeking FDI (Dunning, 1993). Previous empirical works, however, have not usually taken into account the types of FDI, i.e. vertical, horizontal and conglomerate, and how their motivations may differ. Traditional theory is also used to explain foreign investment from the perspective of developed economies. In the case of developing countries such as Thailand, the behaviour of Thai MNCs may not entirely fit with the traditional theory and hence there is the need to explore their behaviour in more detail.

In general, types of FDI are linked to the motives. It is documented in Jansen and Stockman (2004) that horizontal FDI is usually motivated by the need to be close to customer (related to market-seeking motive) due to high trade costs in home country. The firm then have the same or similar businesses at different locations. Vertical FDI, on the other hand, usually occurs when the firm wants to exploit raw materials and labours, reflecting their resource- and efficiency-seeking motives. The firm then decides to fragment its production process in different countries, and each stage of production will be located in countries that offer the lowest costs.

In this paper, we find that substantial parts of OFDI activities do not fit into the established distinction between horizontal and vertical investment. A significant portion of overseas investment can be classified as conglomerate strategy where firms engage in different lines of business from operations at home.

We differentiate strategies pursued by Thai companies by identifying relationship between the companies in Thailand and their foreign affiliates overseas. To obtain an overview of the different strategies, we extract all transactions from the Bank of Thailand database which is a unique data set on FX transaction flows during the period 2005-2012. The data set reports the company name, country of destination as well as the International Standard Industrial Classification (ISIC) of all outward transaction flows from Thailand. Types of industry in Thailand are denoted by INDUS ${ }_{\alpha}$, which provides the basis in distinguishing horizontal, vertical, and conglomerate relationship between companies in Thailand and their affiliates overseas.

To establish whether companies are vertically or horizontally related or completely unrelated (conglomerate strategy), only observing industry type of companies in Thailand and in the host country may not be informative enough about the extent of their horizontal, vertical, or conglomerate relatedness. Therefore, we also consider final outputs produced by companies at home and abroad. These final outputs are denoted by $V_{\alpha}^{\rho}$ and $V_{\beta}^{\sigma}$, respectively. Specifically, our classification is based on the following criteria. If $\operatorname{INDUS}_{\alpha}$ is equal to INDUS ${ }_{\beta}$, it does not automatically imply that companies replicate the same production of goods and services (horizontally related), or are connected through the supply-chain (vertically related). Horizontal OFDI is determined when Thai and overseas companies share the same production/services, and the value of their final outputs are the same $\left(V_{\alpha}^{\rho}=V_{\beta}^{\sigma}\right)$. In contrast, if the values are not the same, even though they share the same industry (INDUS ${ }_{\alpha}=\mathrm{INDUS}_{\beta}$ ), companies in Thailand and their affiliate overseas are classified as having vertically relatedness. For example, if a company in Thailand produces fabric, while its foreign affiliate produces garments, both of them are in clothing-related sector. Yet, they do not have horizontal relatedness because in terms of the production, input produced in Thailand contributes added-value to the final products of foreign affiliate. Thus, they have vertical integration along the supply chain. Vertical integration can also occur when $\operatorname{INDUS}_{\alpha} \neq \operatorname{INDUS}_{\beta}$ but they are on the upstream and downstream linkages across industries. For downstream linkage, output $(\rho)$ in industry $\alpha$ is an input adding value to

\footnotetext{
${ }^{3} \mathrm{HHI}$ is used to measure sectoral and destination concentration of Thai OFDI. HHI $<1,500$ means Thai OFDI is diversified; $1,500<$ HHI $<$ 2,500 means Thai OFDI is moderately concentrated; HHI $>2,500=$ Thai OFDI is highly concentrated.
} 
the output $(\sigma)$ of industry $\beta$ abroad, meaning that $V_{\alpha}^{\rho}$ is less than $V_{\beta}^{\sigma}$. Upstream linkage, on the other hand, occurs when $V_{\alpha}^{\rho}$ is more than $V_{\beta}^{\sigma}$. Conglomerate OFDI arises when operation at home and abroad have nothing in common (INDUS ${ }_{\alpha} \neq \operatorname{INDUS}_{\beta}$ and $V_{\alpha}^{\rho} \neq V_{\beta}^{\sigma}$ ). For instance, Thai manufacturing company acquires foreign bank overseas, or an electricity generating company invests in securities company abroad. Our classification criteria are reported in Table 1.

Table 1 Distinguishing OFDI by types

\begin{tabular}{|c|c|c|}
\hline Strategy & Criteria & Description \\
\hline Horizontal & $\begin{array}{l}\text { INDUS }_{\alpha}=\text { INDUS }_{\beta} \\
\text { And } V^{\rho}{ }_{\alpha}=V_{\beta}^{\sigma}\end{array}$ & $\begin{array}{l}\text { Replication of production by acquiring a foreign facility } \\
\text { in the same industry and on the same stage of the } \\
\text { supply-chain. (Value of outputs are equal) }\end{array}$ \\
\hline \multirow{2}{*}{ Vertical } & $\begin{array}{l}\text { 1) INDUS } \mathrm{I}_{\alpha}=\text { INDUS }_{\beta} \\
\text { (and they are in the same value-chain) } \\
\text { then, if } \mathrm{V}_{\alpha}^{\rho}<\mathrm{V}_{\beta}^{\sigma}=\text { downstream integration } \\
\text { if } \mathrm{V}_{\alpha}^{\rho}>\mathrm{V}_{\beta}^{\sigma}{ }_{\beta}=\text { upstream integration }\end{array}$ & $\begin{array}{l}\text { 1) Sharing the same industry but different stage of } \\
\text { production. (Value of output } \rho \text { in industry } \alpha \text { is } \\
\text { higher/lower than output } \sigma \text { in industry } \beta \text { ) }\end{array}$ \\
\hline & $\begin{array}{l}\text { 2) INDUS } \mathrm{I}_{\alpha} \neq \text { INDUS }_{\beta} \\
\text { (but they are in the same value-chain) } \\
\text { then, if } \mathrm{V}_{\alpha}^{\rho}<\mathrm{V}_{\beta}^{\sigma}=\text { downstream integration } \\
\text { if } \mathrm{V}_{\alpha}^{\rho}>\mathrm{V}_{\beta}^{\sigma}{ }_{\beta}=\text { upstream integration }\end{array}$ & $\begin{array}{l}\text { 2) They are in different industry and production stage } \\
\text { but located within the same value-chain. (Value of } \\
\text { output } \rho \text { in industry } \alpha \text { is higher/lower than output } \sigma \\
\text { in industry } \beta \text { ) }\end{array}$ \\
\hline Conglomerate & $\begin{array}{l}\text { INDUS }_{\alpha} \neq \text { INDUS }_{\beta} \\
\text { And } \mathrm{V}_{\alpha}^{\mathrm{\rho}} \neq \mathrm{V}_{\beta}^{\sigma} \\
\text { (they are NOT in the same value-chain) }\end{array}$ & $\begin{array}{l}\text { Both firms are neither horizontally related through } \\
\text { sharing the same industry nor are they vertically } \\
\text { connected through the supply-chain. }\end{array}$ \\
\hline
\end{tabular}

\subsection{Discussion of Results}

Based on these classifications, we compile the data set which consists of individual outflow transactions of Thai companies during the year 2005-2012 as well as analyse their companies' report. Overall, we find that there are almost 9,000 transactions that we could identify their intra-company relatedness and most of which is horizontally integrated in nature. We find that horizontal investment accounts for more than $50 \%$ of overall transactions while vertical and conglomerate types are more limited (Table 2). The resulting distribution of OFDI strategies for Thai MNCs is consistent with previous empirical works which find that a majority of FDI in the world is of horizontal type (Markusen and Maskus, 2002). We find that conglomerate investment which is thought to be uncommon in most empirical work account for over $20 \%$ of Thai OFDI and is in fact the second most popular investment strategy for Thai MNCs. Conglomerate investment strategy is also the largest investment type with average size per transaction around US\$ 5.1 million, compared to 4.7 and US\$ 4.1 million for vertical and horizontal investment, respectively (Table 2 ).

Table 2 Types of OFDI, Gross Cumulative Value 2005-2012 (Mil US\$)

\begin{tabular}{l|c|c|c|c|c}
\hline OFDI types (Mil US\$) & Sum & Share & Average & Number & Std.Dev. \\
\hline Horizontal & $23,043.9$ & $58.5 \%$ & 4.1 & 5,638 & 13.4 \\
\hline Vertical & $8,004.6$ & $20.3 \%$ & 4.7 & 1,695 & 19.3 \\
\hline Conglomerate & $8,334.7$ & $21.2 \%$ & 5.1 & 1,647 & 15.9 \\
\hline
\end{tabular}

We further investigate these outbound investments in terms of the sector in which they operate and find that manufacturing together with service companies primarily adopt horizontal OFDI strategy (Figure 4). Within manufacturing sector, the most prominent industry is food and beverage industry which prefers to adopt horizontal strategy because retaining and adding customers is the key to driving its revenue growth. Other manufacturing firms such as chemical and chemical products usually undertake horizontal investment to produce the same or similar goods in foreign countries. A smaller proportion of manufacturing firms adopt vertical strategy in both backwardand forward- integration. For backward-integration, food and beverage firms typically look for the host country that provides agro-climatic advantage. On the other hand, forward-integration is mostly in the form of distribution outlet which can be established in any host countries where investors see opportunity to earn more revenues. Meanwhile, 
primary sector especially energy industry has largely adopted vertical strategy (Figure 4). Operations in foreign countries typically cover an entire business value chain from upstream to downstream with ultimate goals to secure energy supply and to create energy innovation. Upstream business (backward-integration) is mainly the exploration and production of oil and gas in resource-abundant countries such as Indonesia, Vietnam, and Australia. Downstream business (forward-integration) includes retail service stations and commercial marketing as well as petroleum and petrochemical products trading which are diversified in several countries in ASEAN, the US, and the Middle East.

Figure 4 Types of Thai OFDI by sector

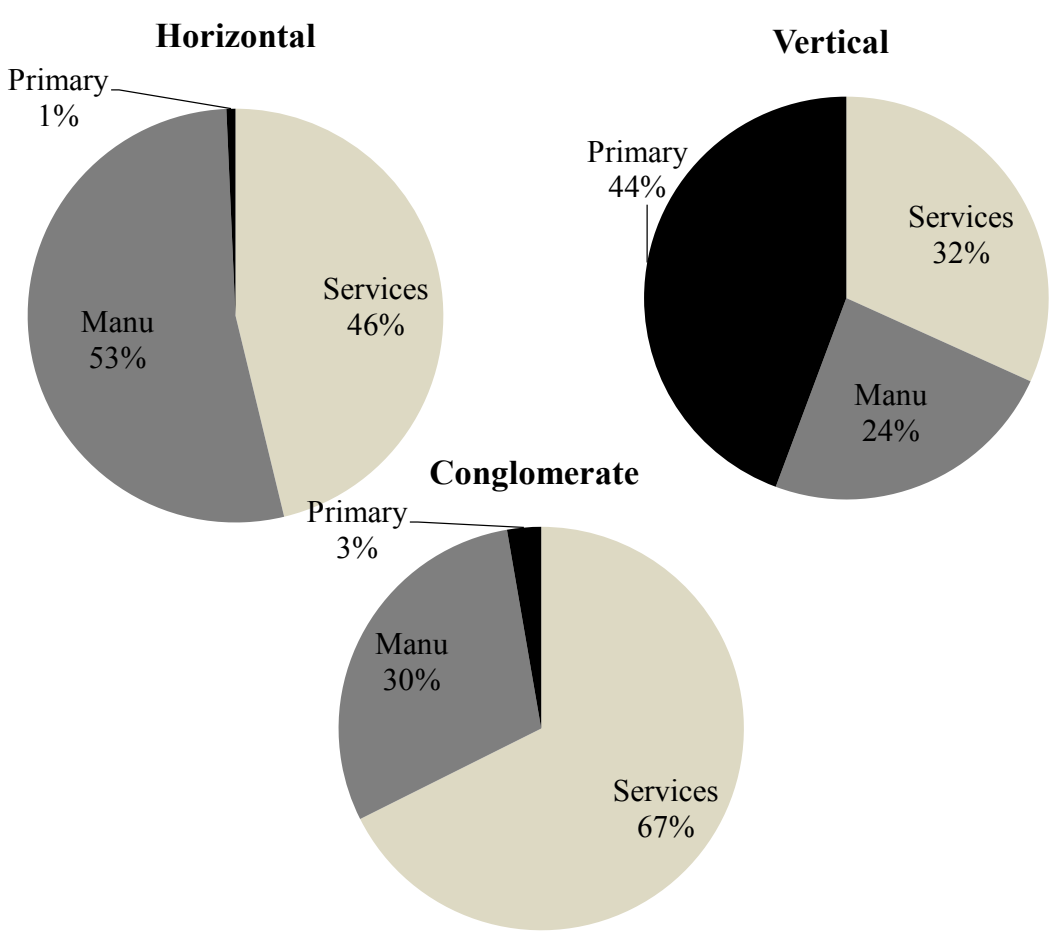

As for conglomerate investment, the strategy typically ranges from sourcing, producing, to selling unrelated goods and services. A bulk of conglomerate Thai OFDI is usually undertaken by large enterprises whose outputs have features of both vertically and horizontally integrated investments. Conglomerate diversification strategy which usually involves lines of business that are unrelated to operations at home are popular among companies in the service and manufacturing sectors (Figure 4). Most of these companies use conglomerate strategy to invest in financial and insurance business abroad mainly to diversify their portfolio and strengthen their financial positions. Companies in the primary sector also use conglomerate strategy to establish holding company in tax haven countries in order to maintain their control over international group of companies, create financial leverage to enhance the transfer of businesses, as well as to reduce tax. It appears that conglomerate investment is undertaken regardless of market size or availability of resource endowments because the investment of this type is primarily for financial purpose, not for expanding market or reducing costs of production.

It is widely believed that horizontal OFDI usually flows to developed countries to serve the local market and vertical OFDI to developing countries to source production of intermediate goods. Our investigation of the destination of OFDI reveals that this is not the case for Thailand. All types of Thai OFDI are found to go mostly to developed countries (Figure 5). In fact, the top-3 destinations for both vertical and horizontal investment strategies are all in developed countries (Table 3 and 4). The reason for this is likely due to the need of Thai MNCs to achieve dual objectives of gaining global market share and upgrading capabilities. While they could already utilize their competitive advantage in other developing countries, they need to also enter into developed countries in order to 
expose themselves to more complicated market and develop their overall capacities. Some large Thai companies have grown interest in M\&A of corporations in developed countries to reap quicker benefits such as well-known branding and access to technology and R\&D skills.

Figure 5. Horizontal, vertical, and conglomerate Thai OFDI classified by host country, from 2005-2012

Gross cumulative value (Million US\$)

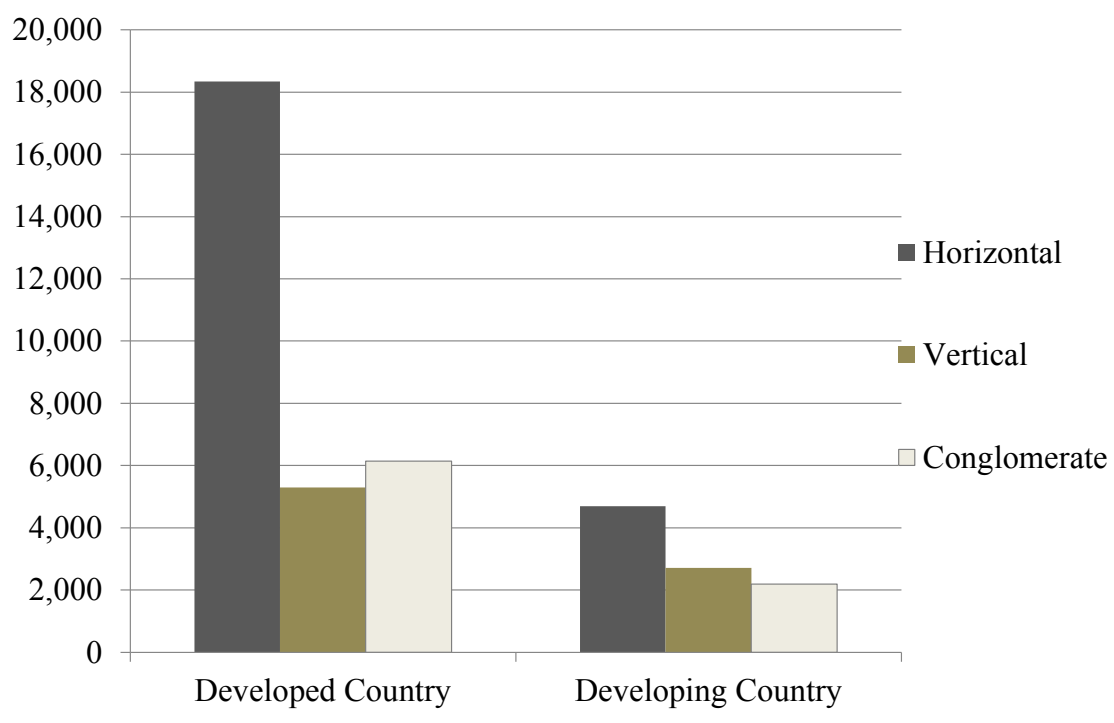

Source: Bank of Thailand

Table 3. Top 10 Horizontal Investment Destination, Gross Cumulative Value 2005-2012 (Mil US\$)

\begin{tabular}{l|c|c|r|r}
\hline & Sum & Mean & Number & Std.Dev. \\
\hline Singapore & $5,486.4$ & 7.9 & 692 & 19.1 \\
\hline United States & $2,868.7$ & 5.5 & 518 & 19.4 \\
\hline Netherlands & $2,292.2$ & 9.2 & 249 & 11.2 \\
\hline United Kingdom & $2,005.3$ & 4.5 & 446 & 7.4 \\
\hline Hong Kong & $1,917.8$ & 6.0 & 319 & 27.0 \\
\hline Japan & $1,466.2$ & 7.9 & 185 & 21.5 \\
\hline Mauritius & 949.4 & 21.6 & 44 & 24.9 \\
\hline Germany & 927.4 & 5.8 & 160 & 6.6 \\
\hline Viet Nam & 786.0 & 1.2 & 639 & 6.7 \\
\hline Indonesia & 785.5 & 2.5 & 320 & 6.3 \\
\hline
\end{tabular}

Table 4. Top 10 Vertical Investment Destination, Gross Cumulative Value 2005-2012 (Mil US\$)

\begin{tabular}{l|r|r|rr}
\hline & Sum & Mean & Number & Std.Dev. \\
\hline Singapore & $1,901.5$ & 5.8 & 327 & 12.8 \\
\hline Australia & $1,233.5$ & 18.1 & 68 & 44.7 \\
\hline Hong Kong & $1,052.6$ & 6.8 & 155 & 32.4 \\
\hline Cayman Islands & 959.7 & 106.6 & 9 & 106.5 \\
\hline Mauritius & 796.3 & 16.9 & 47 & 22.8 \\
\hline United States & 428.9 & 3.3 & 130 & 5.3 \\
\hline Netherlands & 349.2 & 11.6 & 30 & 18.9 \\
\hline Lao People's Democratic Republic & 260.3 & 2.2 & 116 & 4.4 \\
\hline Oman & 219.0 & 3.0 & 74 & 2.8 \\
\hline Viet Nam & 165.4 & 1.0 & 170 & 2.0 \\
\hline
\end{tabular}


Table 5. Top 10 Conglomerate Investment Destination, Gross Cumulative Value 2005-2012 (Mil US\$)

\begin{tabular}{l|r|r|rr}
\hline & Sum & Mean & Number & Std.Dev. \\
\hline Singapore & $2,064.6$ & 6.6 & 313 & 16.1 \\
\hline Hong Kong & $1,674.7$ & 9.1 & 184 & 32.6 \\
\hline Mauritius & 630.2 & 12.4 & 51 & 18.1 \\
\hline United States & 617.2 & 5.3 & 117 & 8.3 \\
\hline Virgin Islands (British) & 567.0 & 9.4 & 60 & 12.0 \\
\hline Switzerland & 565.6 & 11.3 & 50 & 12.5 \\
\hline United Kingdom & 546.1 & 5.8 & 94 & 11.8 \\
\hline Viet Nam & 224.3 & 1.9 & 119 & 3.3 \\
\hline Lao People's Democratic Republic & 215.0 & 1.2 & 176 & 3.2 \\
\hline Netherlands Antilles & 200.0 & 200.0 & 1 & 0.0 \\
\hline
\end{tabular}

Looking closer into the geographical distribution of Thai OFDI in developed countries, we find that Thai MNCs prefer to invest in countries closer to home. Flows to developed countries in Asia account for more than $50 \%$ of vertical and conglomerate investments, and more than one-third for horizontal investment (Figure 6). Singapore and Hong Kong, with their favourable tax regimes, are the preferred destinations for Thai investors to set up holding companies to allocate funds for ultimate investment elsewhere. Conglomerate Thai OFDI also prefer to establish holding companies in international offshore financial centres outside Asia such as Switzerland, Mauritius and British Virgin Islands (Table 5). Some companies may indeed establish holding companies for non-tax reasons such as centralizing allocations of financial resources to their affiliates for more efficient management and balance sheet protection.

Figure 6 Thai OFDI to developed countries (Asian and non-Asian), 2005-2012

Gross cumulative value (Million USD)

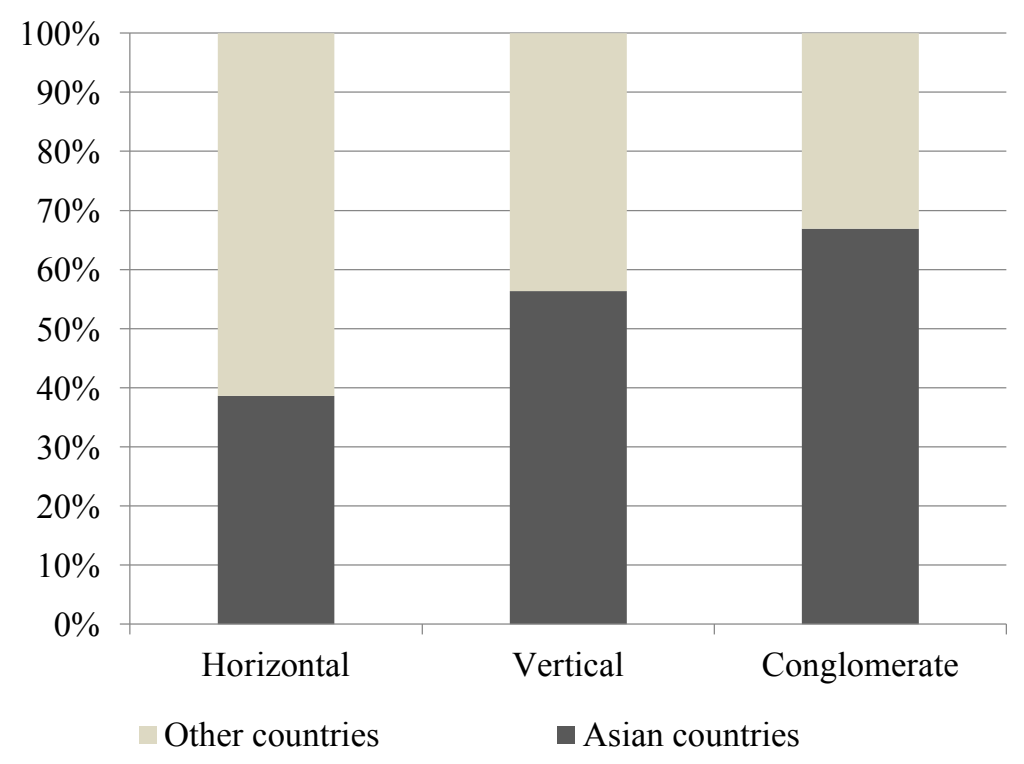

Source: Bank of Thailand 


\section{WHAT DRIVES THAI OUTWARD DIRECT INVESTMENT?}

\subsection{Data Analysis and Methodology}

We use an augmented gravity model to assess the macroeconomic factors driving Thai firms' investment abroad. The gravity model is widely used to analyse international trade flows (Feenstra et al., 2001; Markusen, 2002; Dollar and Kraay 2003) as well as FDI flows from source to host countries (Brainard, 1997; Egger and Pfaffermayr, 2004; Blonigen et al, 2007; Baltagi et al, 2007; Guerin, 2006). Our model aims to measure determinants of outward investment flows between Thailand and host countries by using two main components: the relative market size and the geographic distance between the two economies. Given the core gravity variables that explain the natural pattern of bilateral FDI potential of the home and host countries, other variables are augmented into the model to evaluate their importance in determining Thai OFDI.

This section provides a discussion of our empirical specifications as well as variable description. The aggregate data for Thai OFDI is retrieved from the Bank of Thailand database. The data distinguishing between horizontal, vertical and conglomerate is extracted and classified from a financial market transaction database which is a unique data set capturing gross Thai OFDI flows, source and destination of Thai OFDI flows and industrial classification. In summary, the variables used in our model include host country's GDP, Thai GDP, host country's wage, host country's exchange rate against Thai Baht, host country's natural resources and distance between Thailand and host country. The data and their description are described in Appendix A.

The data consists of yearly bilateral OFDI flows from Thailand to 34 countries around the world from 2005-2012, which accounts for $80 \%$ of total Thai OFDI flows to the rest of the world. Table 6 describes the summary statistics for the main variables used in the regressions. On average, conglomerate investment has the highest value but with large variability. Vertical investment, on the other hand, is almost half the size of conglomerate investment. GDP of host countries is on average much higher than Thai GDP, reflecting the fact that a large proportion of Thai overseas investment is in developed countries with higher income.

Table 6 Summary statistics for all years, 2005-2012.

\begin{tabular}{l|r|r|r}
\hline & Number & Mean & Std.Dev. \\
\hline TDI & 241 & 203.41 & $1,022.19$ \\
\hline HTDI & 190 & 94.11 & 197.32 \\
\hline VTDI & 116 & 51.07 & 119.10 \\
\hline CTDI & 169 & 95.62 & 627.11 \\
\hline GDPH & 230 & $1,455.93$ & $2,853.30$ \\
\hline GDPTH & 241 & 277.07 & 60.99 \\
\hline WAGE & 155 & $8,587.05$ & $9,459.59$ \\
\hline FX & 221 & 24.07 & 20.90 \\
\hline NATRES & 207 & 4.29 & 5.51 \\
\hline DISTANCE & 241 & $6,025.42$ & $4,372.49$ \\
\hline
\end{tabular}

As discussed earlier, we use a gravity type model of FDI as a basis for our analysis and augment by other variables used in previous empirical studies that are relevant in driving OFDI flows. Our main model is:

$$
\mathrm{TDI}=\alpha+\beta_{1} \mathrm{GDPH}+\beta_{2} \mathrm{GDPTH}+\beta_{3} \mathrm{WAGE}+\beta_{4} \mathrm{FX}+\beta_{5} \mathrm{NATRES}+\beta_{6} \mathrm{DISTANCE}+\varepsilon_{\mathrm{it}}
$$

This study utilizes the panel data estimation to estimate yearly Thai OFDI flows to 34 countries during 2005-2012. ${ }^{4}$ To estimate our model, we use panel data analysis to analyse the determinants of Thai OFDI in 4 perspectives: (1) Total OFDI flows, (2) Horizontal OFDI flows, (3) Vertical OFDI flows, and (4) Conglomerate OFDI flows. Thus,

\footnotetext{
${ }^{4}$ The 34 sample host countries are (1) Australia, (2) Austria, (3) Belgium, (4) Cambodia, (5) China, (6) Finland, (7) France, (8) Germany, (9) Hong Kong, (10) India, (11) Indonesia, (12) Ireland, (13) Italy, (14) Japan, (15) Republic of Korea, (16) Lao PDR, (17) Lithuania, (18) Luxembourg, (19) Malaysia, (20) Myanmar, (21) Netherlands, (22) Norway, (23) Philippines, (24) Poland, (25) Portugal, (26) Romania, (27) Singapore, (28) Slovakia, (29) Spain, (30) Switzerland, (31) Taiwan, (32) UK, (33) The US, and (34) Vietnam.
} 
all 4 aspects of OFDI flows are the dependent variables in our estimation, as reported in Table 7. Except for the total OFDI flows in model (1) which utilizes the macro OFDI data, for models (2)-(4), we first aggregate all transaction data in a given country in a given year before estimating OFDI flows to these countries. This is to take into account of multiple individual transaction flows which come from the same companies, albeit at different time, and reflect the fact that investment flows to each country is likely to be driven by the same macro factors.

To test the augmented gravity model for Thailand, we estimate a number of empirical specifications, allowing for an examination of the robustness of our main findings. We first pool all the data using pooled ordinary least square. One drawback of the pooled regression, however, is that it assumes that investment flows to all countries are the same and does not allow for the effects of differential flow behaviour to the specific country. As a result, this may lead to bias estimates because of correlations between the explanatory variables and unobservable effects (Cheng and Wall, 2005). We test whether there are differences across countries by applying the $F$ test that the coefficients on the dummy variables are zero. As the null hypothesis is rejected in all models, we proceed to use fixed-effects (FE) method which introduces the country specific effect by estimating different intercepts for each flow to individual country. The benefit of this method is that it provides consistent estimates regardless of correlation between the specific effects and the explanatory variables. However, as our models contain distance variable which is time invariant and does not vary within the countries, the FE method is not appropriate. We, therefore, adopt the random-effects (RE) method that treats intercepts as random variables across the pooled of outward investment flows to 34 countries. This may provide efficient estimates particularly when there is little or no time-series variation. We test for random effects using Breusch and Pagan $L M$ test and obtain test statistics which reject the null hypothesis in favour of the RE model. In addition, since biased and inconsistent estimates are likely to occur if the individual country flow effect is correlated to some of the explanatory variables, we test whether this is the case by using the Hausman test, which has a $\chi^{2}$ distribution under the null hypothesis of no correlation between the individual country flow effects and our explanatory variables. As reported in Table 7, we cannot reject the null hypothesis in all our specifications. Therefore, based on the $L M$ test, which indicates that there are individual country flow effects, and the Hausman test, which suggests that these effects are not correlated with the other variables in the model, we choose to adopt RE method to estimate our models of overall OFDI and types of OFDI as reported in Table 7.

\subsection{Discussion of Results}

In general, there could be a large number of variables affecting OFDI, as is evident from the existing literature. These variables can broadly be classified into push and pull factors. The push factors are largely the home country factors (e.g. GDP and exchange rate) that facilitate outbound investment by local firms abroad. The pull factors refer to the factors operating in the host countries (e.g. market size, distance and wages).

The results are reported in Table 7 in Model 1-4. These are estimated based on the data of 34 host countries of Thai OFDI which have sufficient information on the independent variables, accounting for around $80 \%$ of the total. Overall, it is found that Thai OFDIs are driven mainly by GDP of both home and host countries as well as distance between countries. While vertical investment is driven by natural resource endowment and horizontal investment by the desire to gain market share, conglomerate investment is driven neither by market size nor relative factor endowments. Here we discuss each variable in the model in turn.

Income, representing the market size for both home and host countries, has been considered as one of the first principal determinants of OFDI. The larger the markets for both home and host economies, the higher the FDI flow should be. A higher home country GDP implies a larger market size which would help a firm to reap economies of scale through specialization (Lall, 1980; Kyrkilis and Pantelidis, 2003). By catering to a large market, Thai firms are able to develop specific strengths or competence which can be used to their advantage while investing abroad (Buckley et al, 2006; Deng, 2004; Taylor, 2002; Zhang, 2003), and hence the significant sign on home country GDP in all specifications. As income rises, and consistent with investment development path theory, Thai enterprises likely invest more overseas.

The host country GDP is significant for total and horizontal OFDI models but not for vertical and conglomerate OFDI. This is mainly because firms in vertical strategy focus more on abundance of natural resources when investing overseas than on market size, as indicated in the significant sign of natural resource variables in driving 
vertical OFDI flows. While vertical investment is driven by the desire to gain access to natural resources, conglomerate strategy is driven by neither the desire to replicate or outsource production overseas. Rather the conglomerate investment is driven by financial motives that are often lacking in the conventional international economics literature. A number of companies in manufacturing sector that pursue vertical strategy also invest in financial or holding companies abroad.

Several empirical studies (e.g. Froot and Stein, 1991) find that an appreciation of local currency usually supports OFDI and the coefficient of FX is expected to be negative. Exchange rate, however, does not seem to be an important factor in driving Thai OFDI. Analysis of the data reveals that, with the exception of a few currencies, Thai baht has remained largely stable during the study period against most of the host country currencies. The proliferation of Thai OFDI is, therefore, driven by other factors rather than the movement of bilateral exchange rate.

According to gravity-type model explanation, bilateral trade and investment fall as distance between origin and destination rises. Distance enters significantly as a driver of overall OFDI. Our coefficients of the distance variable are significant with a negative sign, suggesting that geographical distance is indeed one of the crucial factors for outward investment consideration. This suggests that countries located in the same region likely attract more investment from Thailand.

Table 7. Determinants of Overall OFDI and Types of OFDI

\begin{tabular}{|c|c|c|c|c|}
\hline $\begin{array}{c}\text { Explanatory } \\
\text { Variables } \\
\end{array}$ & $\begin{array}{c}(1) \\
\text { Total }\end{array}$ & $\begin{array}{c}(2) \\
\text { Horizontal } \\
\end{array}$ & $\begin{array}{c}(3) \\
\text { Vertical } \\
\end{array}$ & $\begin{array}{c}(4) \\
\text { Conglomerate } \\
\end{array}$ \\
\hline F-test & $\begin{array}{c}F(22,112)=4.73 \\
\text { Prob }>F=0.00\end{array}$ & $\begin{array}{l}F(21,89)=3.73 \\
\text { Prob }>F=0.00\end{array}$ & $\begin{array}{l}F(8,63)=3.86 \\
\text { Prob }>F=0.00\end{array}$ & $\begin{array}{l}F(8,80)=3.67 \\
\text { Prob }>F=0.00\end{array}$ \\
\hline LM test & $\begin{array}{c}\chi^{2}=38.55 \\
\text { Prob }>\chi^{2}=0.00\end{array}$ & $\begin{array}{c}\chi^{2}=18.79 \\
\text { Prob }>\chi^{2}=0.00\end{array}$ & $\begin{array}{c}\chi^{2}=6.22 \\
\text { Prob }>\chi^{2}=0.01\end{array}$ & $\begin{array}{c}\chi^{2}=22.26 \\
\text { Prob }>\chi^{2}=0.00\end{array}$ \\
\hline Hausman test & $\begin{array}{c}\chi^{2}=5.25 \\
\text { Prob }>\chi^{2}=0.39\end{array}$ & $\begin{array}{c}\chi^{2}=3.47 \\
\text { Prob }>\chi^{2}=0.63\end{array}$ & $\begin{array}{c}\chi^{2}=3.31 \\
\text { Prob }>\chi^{2}=0.85\end{array}$ & $\begin{array}{c}\chi^{2}=10.75 \\
\text { Prob }>\chi^{2}=0.06\end{array}$ \\
\hline Method & RE & RE & $\mathbf{R E}$ & $\mathbf{R E}$ \\
\hline GDPH & $\begin{array}{c}.5111794 * * * \\
(2.60)\end{array}$ & $\begin{array}{c}.5652722 * * * \\
(2.66)\end{array}$ & $\begin{array}{c}-.3192926 \\
(-0.86)\end{array}$ & $\begin{array}{c}.0109095 \\
(0.04)\end{array}$ \\
\hline GDPTH & $\begin{array}{c}4.57029 * * * \\
(7.59)\end{array}$ & $\begin{array}{c}4.249201 * * * \\
(6.01)\end{array}$ & $\begin{array}{l}4.272975^{* * * *} \\
(3.5)\end{array}$ & $\begin{array}{c}3.00974 * * * \\
(3.10)\end{array}$ \\
\hline WAGE & $\begin{array}{c}.3455307 \\
(0.79)\end{array}$ & $\begin{array}{c}.1036364 \\
(0.22)\end{array}$ & $\begin{array}{c}.2002137 \\
(0.790)\end{array}$ & $\begin{array}{c}-.0568729 \\
(-0.10)\end{array}$ \\
\hline FX & $\begin{array}{c}.5347107^{* *} \\
(2.32)\end{array}$ & $\begin{array}{c}.4035837^{*} \\
(1.68)\end{array}$ & $\begin{array}{c}-.1154413 \\
(0.925)\end{array}$ & $\begin{array}{c}.3756449 \\
(1.30)\end{array}$ \\
\hline NATRES & $\begin{array}{c}.0183264 \\
(0.33)\end{array}$ & $\begin{array}{c}-.0106015 \\
(-0.18)\end{array}$ & $\begin{array}{c}.1357185^{*} \\
(1.66)\end{array}$ & $\begin{array}{c}.015902 \\
(0.26)\end{array}$ \\
\hline DISTANCE & $\begin{array}{c}-1.768521 * * * \\
(-2.86)\end{array}$ & $\begin{array}{c}-1.557053 * * * \\
(-2.62)\end{array}$ & $\begin{array}{c}-.8720578 \\
(-0.60)\end{array}$ & $\begin{array}{c}-1.148631^{*} \\
(-1.73)\end{array}$ \\
\hline No. of observation & 141 & 117 & 72 & 89 \\
\hline $\mathrm{R}^{2}$ & $\begin{array}{c}\text { Within }=0.3612 \\
\text { Between }=0.3937 \\
\text { Overall }=0.4303\end{array}$ & $\begin{array}{c}\text { Within }=0.3132 \\
\text { Between }=0.3925 \\
\text { Overall }=0.3523\end{array}$ & $\begin{array}{c}\text { Within }=0.2640 \\
\text { Between }=0.1608 \\
\text { Overall }=0.1824\end{array}$ & $\begin{array}{c}\text { Within }=0.1251 \\
\text { Between }=0.2547 \\
\text { Overall }=0.1723\end{array}$ \\
\hline
\end{tabular}

Note: The t-statistics are in the parentheses. ${ }^{* * *}, * *$, and ${ }^{*}$ denotes significance level at the $1 \%, 5 \%$, and $10 \%$ level, respectively.

Wage does not appear to play an important role in determining Thai OFDI. Availability of low cost labour is expected to stimulate OFDI of vertical type where the cheap wage is considered to be an important factor (Sahoo, 2006; Wheeler and Mody, 1992; Kumar, 1994). However, we do not find a statistical significant relationship between wages and vertical OFDI, which may be explained by the fact that during the period of study wages in Thailand remained low and was not the main factor in driving OFDI. ${ }^{5}$

${ }^{5}$ In October 2011, the Central Wage Committee passed a resolution approving a proposal to raise the daily minimum wage to 300 baht, effective since April $1^{\text {st }}, 2012$ in 7 pilot provinces, namely, Bangkok, Nakhon Pathom, Nonthaburi, Samut Prakan, Samut Sakhon, Phuket, and Pathum Thani. Then on January $1^{\text {st }}, 2013$, the 300 -baht daily minimum wage was further implemented in the remaining provinces. 
Overall, determinants of Thai OFDI mostly turn out to be in line with expectation, with strong evidence for marketseeking OFDI. However, we find no evidence for the efficiency-seeking OFDI where firms go abroad to reduce costs. Higher labour cost in the host economies does not deter Thai multinational from investing in those economies. Thai OFDI tends to be market-seeking in nature with the size of host countries an important consideration. Most MNCs, regardless of their types, also tend to invest in countries with closer proximity. The important variable which appears significant in all models is Thai GDP. Higher income is clearly associated with more OFDI flows and is consistent with the investment development path framework which seeks to explain the dynamic relationship between FDI and the level of development of a given country (Dunning, 1981; Dunning and Narula, 1996 and Narula and Dunning 2010).

\section{CONCLUSION}

Like other countries, the path to outward direct investment of Thai companies has been long and passive. It had taken more than 20 years before the acceleration of outward direct investment of Thai enterprises actually materialised. Despite being a late comer, the proliferation of Thai OFDI in recent years has been one of the most striking economic developments and a subject of much debate. This paper analyses the trends, patterns and determinants of outward direct investment in Thailand using both macro and firm-level FX transaction data from 2005-2013. The comprehensive nature of the data set used in this study allows for a deeper analysis of the patterns and main drivers of various types of Thai OFDI as well as provides the stepping stone to directly infer the horizontal, vertical and conglomerate linkages at the disaggregated level.

This study provides a number of interesting features and implications of Thai OFDI that have not been previously discussed. First, the majority of Thai OFDI is found to be of horizontal type with vertical and conglomerate investment sharing less than half of the overall total. Second, horizontal investment is driven mainly by the desire to gain market share and vertical investment by relative factor endowments. This means that the majority of Thai MNCs are market-seeking in nature. The lack of natural resources and higher labour cost do not necessarily deter Thai MNCs from investing in those economies. Third, conglomerate investment which has been largely ignored by previous empirical studies accounts for a significant part of outward investment and is driven mainly by financial motives. This implies that not all overseas investment is driven by production purposes as previously suggested by past theories. Many MNCs actually invest abroad to diversify their portfolio, strengthen their financial positions as well as to reduce tax. Fourth, most Thai MNCs tend to invest in countries with closer proximity. Almost $60 \%$ of conglomerate investment is located in Asia, compared to $47 \%$ and $45 \%$ for vertical and horizontal investment, respectively. This is consistent with the gravity model of FDI which suggests that FDI is negatively related to the distance between home and host countries. The growing distance between the two countries possibly impair the chances to attract Thai OFDI due to the lack of knowledge, familiarity and understanding of foreign markets. Fifth, in contrast to what is commonly believed that horizontal OFDI usually flows to developed countries to serve the local market and vertical investment to developing countries to source production of intermediate goods, Thai investors have simultaneously entered into developed and developing countries, with all types of investment going mostly to developed countries. This implies that the investment path of developing countries' MNCs such as Thailand may not always follow those of their developed countries' counterparts. While they can already utilize their competitive advantage in other developing countries, they need to also enter into developed countries to expose themselves to more complicated market and develop their capacities. It is not surprising, therefore, to see growing interest of Thai MNCs in acquiring corporations in advanced countries, reaping quicker benefits from company branding, established markets, and technological advancement.

This paper provides an important policy lesson that MNCs' investment strategies are necessarily diverse. It is, therefore, important for policy makers to design OFDI promotion policies that tailor to their needs and appropriately complement their strategies in the global arena. Due to the complex nature of overseas investment, however, private sector for their part should also actively communicate with government agencies about their investment needs, join in government-support initiatives, and involve in discussions of new policies and measures. This is to ensure that government policies are effective and truly benefit Thai businesses in venturing overseas.

Our research contributes to the literature by filling in the knowledge gap in understanding international investment patterns and their determinants. However, given that MNCs operations will become more and more complicated, 
further research is needed to fully understand the patterns and drivers of these enterprises' investment. In the case of Thailand, the country has long been one of the most attractive destinations of inward foreign direct investment. This implies that not all OFDI is invested by Thai-controlled companies and foreign-controlled companies registered in Thailand likely also venture abroad. Due to the different nature of their ownership and business objectives, Thai and foreign-controlled firms are likely to differ in their investment patterns and incentives. More research exploring ownership types of OFDI should, therefore, be useful and provide deeper insights into MNCs' overseas investment behaviour as well as appropriate policy recommendations to ensure that international expansion truly benefits the Thai economy.

\section{AUTHOR BIOGRAPHIES}

Dr. Tientip Subhanij is a faculty member at the College of Management, Mahidol University. Previously, she was the Division Executive at the Economic Research Department, Bank of Thailand. She has a PhD in Economics from the University of Cambridge and has published widely in the area of international finance and business, banking and macroeconomic policies.

Ms. Chitchanok Annonjarn is a Senior Economist at the Macroeconomic and Monetary Policy Department, Bank of Thailand. Her research interests include international business, capital flows and capital account liberalization policies.

\section{REFERENCES}

Alfaro, L., \& Charlton, A. (2009). Intra-industry foreign direct investment. American Economic Review, 99(5), $2096-2119$.

Braconier, H., Norback, P.H., \& Urban, D. (2005). Multinational enterprises and wage cost: vertical FDI revisited. Journal of International Economics, 67, 446-470.

Brainard, S.L. (1997). An Empirical Assessment of the Proximity Connection Trade-off Between Multinationals Sales and Trade. American Economic Review, 87, 520-544.

Baltagi, B.H., Egger, P., \& Pfaffermayr, M. (2007). Estimating Models of Complex FDI: Are There Third-Country Effects? Journal of Econometrics, 140(1), 260-81.

Blonigen, B.A., Davies, R.B., Waddell, G.R., \& Naughton, H.T. (2007). FDI in Space: Spatial Autoregressive Relationships in Foreign Direct Investment. European Economic Review, 51, 1303-25.

Brainard, S.L. (1997). An Empirical Assessment of the Proximity-Concentration Trade-Off between Multinational Sales and Trade. American Economic Review, 87(4), 520-44.

Buckley, P.J., Cross, A.R., Tan, H., Voss, H., \& Liu, X. (2006). An Investigation of Recent Trends in Chinese Outward Direct Investment and Some Implications for Theory. Centre for International Business University of Leeds Working Paper.

Cheng, I., \& Wall, H. (2005). Controlling for Heterogeneity in Gravity Model of Trade and Integration. Federal Reserve Bank of St. Louis Review, 87(1), 49-63.

Cheewatrakoolpong, K., \& Boonprakaikawe, J. (forthcoming). Factors Influencing Outward FDI: case study of Thailand in comparison with Singapore and Malaysia.

Decharuk, K., Leelapornchai, P., \& Udomkerdmongkol, M. (2009). Thailand's Investment in the Post-Crisis Era: Issues and Challenges. Bank of Thailand Discussion Paper, DP/04/2009.

Deng, P. (2004). Outward investment by Chinese MNCs: Motivations and implications. Business Horizons, 47(3), 8-16.

Dollar, D., \& Kraay, A. (2003). Institutions, Trade and Growth. Journal of Monetary Economics, 50, 133-62.

Dunning, J.H. (1981). Explaining the international direct investment position of countries: Towards a dynamic or developmental approach. Review of World Economics (Weltwirtschaftliches Archiv), 117(1), 30-64.

Dunning, J.H. (1993). Multinational Enterprises and the Global Economy. New York, NY and London: Addison-Wesley.

Dunning, J.H. (2009). Location and the Multinational Enterprise: John Dunning's Thoughts on receiving the Journal of International Business 2008 Decade Award. Journal of International Business Studies, 40(1), 20-34.

Dunning, J.H., \& Narula, R. (1996). Foreign Direct Investment and Governments: Catalysts for Economic Restructuring. London: Routledge.

Egger, P., \& Pfaffermayr, M. (2004). Distance, trade and FDI: A SUR Hausman-Taylor approach. Journal of Applied Econometrics 19, 227-46.

Feenstra, R.C., Markusen, J.R., \& Rose, A.K. (2001). Using the gravity equation to differentiate among alternative theories of trade. Canadian Journal of Economics 34, 430-47.

Froot, K., \& Stein., J. (1991). Exchange Rates and FDI: An Imperfect Capital Markets Approach. Quarterly Journal of Economics 106, 1191-1127.

Guerin, S.S. (2006). The Role of Geography in Financial and Economic Integration: A Comparative Analysis of Foreign Direct Investment, Trade and Portfolio Investment flows. World Economy 29(2), 189-209. 
Guillen M., \& Garcia-Canal, E. (2009). The American Model of the Multinational Firm and the New Multinationals from Emerging Economies, Academy of Management Perspectives, 23(2), 23-35.

Helpman, E. (1984). A simple theory of trade with multinational corporations. Journal of Political Economy ,92, $451-471$.

Helpman, E., Melitz, M. \& Yeaple, S.R. (2003). Export versus FDI. NBER Working Paper Series No. 9439. National Bureau of Economic Research, Cambridge, MA, United States.

Helpman, E., Melitz, M. \& Yeaple, S.R. (2004). Export versus FDI with heterogeneous Firms. American Economic Review 94 (1).

Herger, N., \& McCorriston, S. (2014). Horizontal, Vertical, and Conglomerate FDI: Evidence from Cross Border Acquisitions. Study Center Gerzensee Working Paper 14.02.

Jansen, W.L., \& Stokman, A.C.J. (2004). Foreign Direct Investment and International Business Cycle Comovement. European Central Bank Working Paper Series, No. 401.

Johnston, R.B., Darbar S.M., \& Echeverria C. (1997). Sequencing Capital Account Liberalization - Lessons from the Experiences in Chile, Indonesia, Korea, and Thailand. IMF Working Paper, WP/97/157.

Kim, C., \& Park, D. (2015). Emerging Asian MNCs. Asia Pacific Business Review, 21 (4), 457-463.

Kumar, N. (1994). Multinational Enterprises and Industrial Organization. New Delhi: Sage Publications.

Kyrkilis, D., \& Pantelis P. (2003). Macroeconomic determinants of Outward Foreign Direct Investment. International Journal of Social Economics, 30 (7), 827-836.

Lall, S. 1980. Monopolistic Advantages and Foreign Involvement by U.S. Manufacturing Industry. Oxford Economic Papers, $32,102-22$.

Markusen, J.R., \& Venebles, T. (1998). Multinational Firms and the New Trade Theory. Journal of International Economics, 46, 183-203.

Markusen, J.R., \& Maskus, K.E. (2002). Discriminating among Alternative Theories of the Multinational Enterprise. Review of International Economics, 10, 694-707

Markusen, J.R. (2002). Multinational Firms and the Theory of International Trade. Cambridge (Mass.): MIT Press.

Narula, R., \& Dunning, J.H. (2010). Multinational Enterprises, Development and Globalisation: Some Clarifications and a Research Agenda, Oxford Development Studies, 38 (3), 263-287.

Pananond, P. (2004). Thai Multinationals After the Crisis: Trends and Prospects, ASEAN Economic Bulletin, 21 (1), $106-26$.

Sahoo, P. (2006). Foreign Direct Investment in South Asia: Policy, Trends, Impact and Determinants. ADB Institute Discussion paper 56.

Sermcheep, S. (2013). Foreign Direct Investment and Economic Growth: The Case of Thailand's Inward and Outward FDI. Paper presented at Ninth Annual APEA Conference, Osaka.

Subhanij, T., \& Annonjarn, C. (2014). Thai Outward Direct Investment: Trends, Patterns and Determinants. Proceedings of 28th International Business Research Conference, Barcelona.

Taylor, R. (2002). Globalization Strategies of Chinese Companies: Current Developments and Future Prospects. Asian Business and Management, 1, 209-225.

UNTAD (United Nations Conference on Trade and Development) (2014). World Investment Report 2014: Investing in the SDGs: An Action Plan. New York and Geneva: UNCTAD.

Wee. K.H. (2007). Outward Foreign Direct Investment by Enterprises from Thailand. UNCTAD Transnational Corporations, 16 (1), 89-113.

Wheeler, D., \& Ashoka, M. (1992). International Investment Location Decisions: the Case of US Firms. Journal of International Economics 33 (1-2), 57-76.

Zhang, Y. (2003). China's Emerging Global Businesses: Political Economy and Institutional Investigations. Basingstoke: Palgrave Macmillan. 
APPENDIX A Variables Description and Hypothetical Signs for Thai OFDI Determinants

\begin{tabular}{|c|c|c|c|}
\hline Variable & Explanation & Source & Expected Sign \\
\hline \multicolumn{4}{|c|}{ Dependent Variables } \\
\hline TDI & $\begin{array}{l}\text { Total bilateral OFDI outflow from } \\
\text { Thailand to the host country } \\
\text { (Million US\$) }\end{array}$ & Bank of Thailand & \\
\hline HTDI & $\begin{array}{l}\text { Horizontal OFDI outflow from } \\
\text { Thailand to the host country } \\
\text { (Million US\$) }\end{array}$ & Bank of Thailand & \\
\hline VTDI & $\begin{array}{l}\text { Vertical OFDI outflow from } \\
\text { Thailand to the host country } \\
\text { (Million US\$) }\end{array}$ & Bank of Thailand & \\
\hline CTDI & $\begin{array}{l}\text { Conglomerate OFDI outflow from } \\
\text { Thailand to the host country } \\
\text { (Million US\$) }\end{array}$ & Bank of Thailand & \\
\hline \multicolumn{4}{|c|}{ Explanatory Variables } \\
\hline GDPH & $\begin{array}{l}\text { GDP of the host country reflects its } \\
\text { market size (Billion US\$) }\end{array}$ & $\begin{array}{l}\text { IMF World Economic Outlook } \\
\text { Database }\end{array}$ & + \\
\hline GDPTH & $\begin{array}{l}\text { GDP of Thailand reflects its market } \\
\text { size (Billion US\$) }\end{array}$ & $\begin{array}{l}\text { IMF World Economic Outlook } \\
\text { Database }\end{array}$ & + \\
\hline WAGE & $\begin{array}{l}\text { Labour earnings of the host country } \\
\text { represents labour cost (US\$) }\end{array}$ & $\begin{array}{l}\text { International Labour Organization } \\
\text { (ILO) database and Eurostat }\end{array}$ & - \\
\hline FX & $\begin{array}{l}\text { Average annual exchange rate of } \\
\text { Thai Baht to the host country's } \\
\text { currency represents amount of the } \\
\text { Thai Baht purchasing one unit of the } \\
\text { host country's currency (Thai Baht } \\
\text { per } 1 \text { unit of foreign currency) }\end{array}$ & Bank of Thailand & - \\
\hline NATRES & $\begin{array}{l}\text { The percentage of fuels, ores, and } \\
\text { metals exports to total merchandise } \\
\text { exports of the host country is } \\
\text { proxied for natural resources } \\
\text { abundance (Index) }\end{array}$ & $\begin{array}{l}\text { The World Development } \\
\text { Indicators (WDI) }\end{array}$ & + \\
\hline DISTANCE & $\begin{array}{l}\text { Distance between the capital of the } \\
\text { host country and Thailand } \\
\text { (Kilometres) }\end{array}$ & http://www.distancefromto.net/ & - \\
\hline
\end{tabular}


NOTES 